\title{
Development Strategies of Fiscal Programs for Universities in Korea - With Focused on Estimation of Effect of Restructuring of University Financial Support Project on University Competitiveness
}

\author{
Sang-Yup Lee \\ Konkuk University, Korea
}

Copyright@2019 by authors, all rights reserved. Authors agree that this article remains permanently open access under the terms of the Creative Commons Attribution License 4.0 International License

\begin{abstract}
Objectives: In Korea, as various university financial support projects such as CK, PRIME, ACE, WE-UP project will be completed in 2018. A reorganization plan should be prepared for the direction and support method of the university financial support project. Statistical analysis: In this paper, I examined the basic direction and performance of university financial support project, and estimated the effect of integration of university financial support project. The main method of analysis is system dynamics. The simulation model is composed of variables affecting university finance such as university education competitiveness, entrepreneurial ecosystem construction, and job creation scale, and the effect of university innovation support project on the competitiveness of university education is estimated and analyzed. Findings: The simulation results and the sensitivity analysis results of the individual important variables are estimated from the improved method, the stronger level by 1.1, and the improved and enhanced level by 1.2 are presented. In the case of university competitiveness variables, which are considered to be the most important, gradual improvement can be expected from 2012 to the promotion of university financial support projects, and it can be assumed that this trend will continue in the long term. If the past level is maintained, it will be 1.65 (assuming 2012 is 1) in 2028. If the university innovation support project is estimated to be a slightly improved scenario from 2019, it will be 1.68 in 2028, and be improved to a better level and 1.73 in the strong level. When applying these estimates, if the desired level of 2028 is set politically (ex, 1.9 or 2), then to what extent should the level of other variables be improved to achieve this (ex, to what extent the level of the scenario should be improved) may be inferred of estimates. Improvements: With the goal of making the right use of government funded projects and becoming a universalized
\end{abstract}

university at a global level, this university can survive by constantly researching which departments to characterize.

Keywords Fiscal Programs for Universities, the Fourth Industrial Revolution, University, Educational Competitiveness, University Innovation Support Project, Korea

\section{Introduction}

In Korea, the size and type of financial support programs for universities increased greatly in the 2000s. Half-price tuition policies were implemented since the 2010s. The evaluation of university structural reforms has begun and mandatory admission cuts have been made for lower-level universities [1].

The school-age population has started to decline, and university admission resources are likely to plummet in the 2020 school year. The diversity of population structure and education demanders, the entry of aging society and the opening of the era of the fourth industrial revolution are rapidly changing. In the changing environment of university education, universities are required to change their constitution [2]. In order to strengthen the educational competitiveness of universities, there should be a serious discussion on how to develop the university education, how to secure the necessary budget for such development, and how the university financial support project should be changed[3].

In the meantime, the financial support for the higher education of the government has been supported by the special purpose projects, so that the problems of redundant investment and inefficiency of investment have been continuously raised [4]. As various university 
financial support projects such as CK, PRIME, ACE, WE-UP project will be completed in 2018. A reorganization plan should be prepared for the direction and support method of the university financial support project through the review of the overall structure of the university financial support project. If we integrate with the university's financial support project, how will we design the project in order to enhance the competitiveness of the university, what kind of policy effect will the new general financial support project bring in mid to long term? In addition, university financial support projects need objective prediction and rational alternative exploration on how to link with other higher education policies, such as basic university capacity assessment.

In this paper, I examined the basic direction and performance of university financial support project, and estimated the effect of integration of university financial support project. Based on this, I suggested prescription for the development plan of university financial support project. The main method of analysis is system dynamics. Through the FGI, I collected opinions about the nature of the university financial support project, the problems of the existing projects, and the prediction of the future pattern for the professionals who have evaluated the university financial support project and the experts [5]. The simulation model is composed of variables affecting university finance, such as university education competitiveness, entrepreneurial ecosystem construction, and job creation scale, and the effect of university innovation support project on the competitiveness of university education is estimated and analyzed. The analysis period was from 2012 to 2028. It is assumed that the projects that have been underway since 2012 will be implemented by 2018 and then will be reorganized from 2019. The effects of the business reforms since 2019 were estimated by 2028. The competitiveness of university education is divided into units of one year.

\section{Achievements and Theoretical Background of the University Financial Support Project}

\subsection{Achievements of Major University Financial Support Project}

Look at the policy objectives and support size of major special purpose projects. First, 110 universities and 337 project teams were selected for the CK project aiming at improving the constitution of the university and establishing a specialization base.

Second, the PRIME business is aimed at strengthening students' career capacity and eliminating mismatches in the workforce. A total of 21 universities were selected, with a total of 15 billion won for a large project team and 5 billion won for a small project team, which lasted for three years. Third, The CORE project was funded with a total of 1.2-3.7 billion won per year for 19 universities with the goal of fostering the humanities and strengthening the capacity of humanities. It's a business that lasted three years.

The results of these financial support programs are as follows. First, In the case of the CK project, the reduction in the number of students was 18,000 in 96 schools, the development of curriculum for specialization, curriculum structure and reorganization of 78 projects in 40 schools, nurturing customized talent linked to local areas, balanced development between disciplines. Second, In case of PRIME business, 5,351 students moved to the future promising field and tried to reform the curriculum structure focused on social and industrial demand and to improve the quality of university education. Third, In the case of the CORE project, the number of students attending courses in the humanities in other universities increased, the number of lectures in the humanities increased, and the improvement of the humanities promotion system in universities.

\subsection{Reorganization Direction of University Financial Support Project}

Until now, the budget for university funded projects has included all elements such as research, manpower development, and regional balance in one funded project. However, since it is impossible to manage the performance of a business with various purposes properly, it is necessary to simplify the business contents in order to improve the technical efficiency. And there was a possibility that individual universities could receive ACE, CK, LINC+, and PRIME at the same time. The problem was that the burden of evaluation increased[6].

Until now, criticism has been raised that detailed types and evaluation indexes are overly detailed in each business, hindering the possibility of autonomous development of individual universities. Therefore, most financial support projects related to undergraduate programs will be unified into a general financial support project. The University Innovation Support Project reorganized in 2019, will set a large framework for the type of project, and let individual universities decide the details to be included in the project, and at the same time, improve the university autonomy to the maximum.

\subsection{Theoretical Background for the Development of an Analysis Model}

System Dynamics is an academic discipline that analyzes system changes over time and analyzes the cause and effect of changes through feedback process $[5,8]$. System, which is the basic element of system dynamics, is made up of components of the system, that is, the system, called an object. The entities that make up the system correlate with other entities and observe how entities 
change over time through interactions among entities[2]. In this study, I observed the change of output variable on the change of the input variable of the effect on university innovation support project and grasped the interrelationship between external and internal entities constituting the competitiveness system of university education. In order to clarify the interrelationship between the entities that make up the system, the relationship between these entities in system dynamics is analyzed by using logic such as Feedback Theory, Cause and Effect Theory, Hard Variable and Soft Variable, Time Delay Effect Theory and Non-Linearity Theory Explain.

\section{Simulation of the Effect of University Innovation Support Project on University Competitiveness}

\subsection{Analysis Structure and Causal Map}

In this study, the demand for the necessity of restructuring the university is increasing due to the decrease of the school age population due to the entrance of aged society. This is supposed to lead to an increase in input factors such as various university financial support projects.[5, 2] (These contents of Chapter 3 were mainly cited in Lee, Sang-Yup's advisory contents. 48-74. In Ju, Sang-Hyeon, 2017 KISTEP internal report). It is assumed that effective policy intervention is necessary to determine the environmental factors, the amount of input, and the effective promotion of university support projects.

Figure 1 is causal map composed of causal relationship using system dynamics. Analysis of effectiveness of University Innovation Support Project through consolidation and closure of university support projects. The mutual influence relationship between variables such as social and industrial centered school business structure, entrepreneurial ecosystem construction, size of employment creation, and competitiveness of university education are expressed in feedback diagram.

\subsection{Feedback Loop Search}

Through the generated causal maps, I have searched for strengthened loops and balanced loops. This enables us to explore what policy interventions are effective in the overall system of university financial support projects.

\subsubsection{The Feedback Effect of the Scale of the University Financial Support Project Expense (Reinforcing Loop: R1)}

The logic of the feedback analysis loop of the scale of the financial support project expenses of the university is as follows [Figure 2]. As the necessity of university restructuring is increased, the cost of financial support for universities will increase. As a result, competition among universities will be intensified, resulting in an increase in university students' fatigue. Increased university fatigue lowers the competitiveness of comparative advantage in universities, which has the effect of lowering the competitiveness of university education. The low educational competitiveness of universities leads to a vicious circle which again necessitates the structural reform of the university.

\subsubsection{The Feedback Effect of Integration and Closure of University Financial Support Project (Balancing Loop: B1)}

The logic of the loop effect feedback loop of the university financial support project is as follows [Figure 3]. If the policy of cultivating customized talent linked to the region is not properly implemented, the establishment of the entrepreneurial ecosystem and the mismatch of manpower occur, and the scale of the entrepreneurial revitalization and the employment creation become worse. This phenomenon lowers the competitiveness of comparative advantage in the end, which is a feedback circulation structure that emphasizes the necessity of consolidation of university financial support projects.

\subsubsection{Reform of University Structure and Feedback Effect of Job Creation (Reinforcing Loop: R2)}

The logic of the feedback effect loop of university structure reform and job creation is as follows [Figure 4]. The youth unemployment rate, the size of employment creation, and the increasing mismatch of manpower will lead to the necessity of university restructuring. As the necessity of university restructuring is increased, various university financial support projects will be promoted. This reduces the effectiveness of differentiation between the fundraising and the university financial support projects through redundant support and selection, and eventually a vicious cycle such as human error mismatching is repeated. 


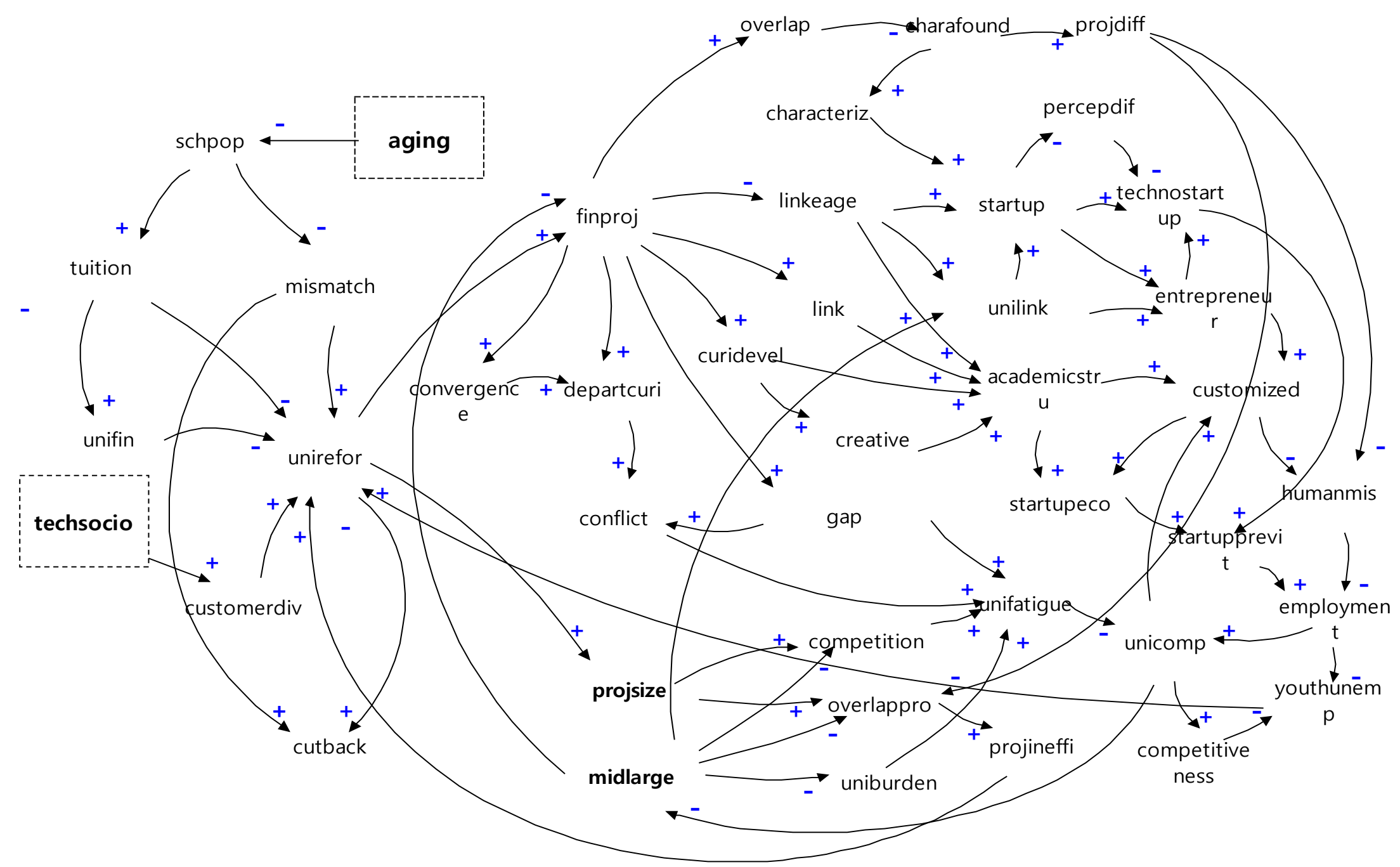

Figure 1. Full Causal Map of University Financial Support Project 


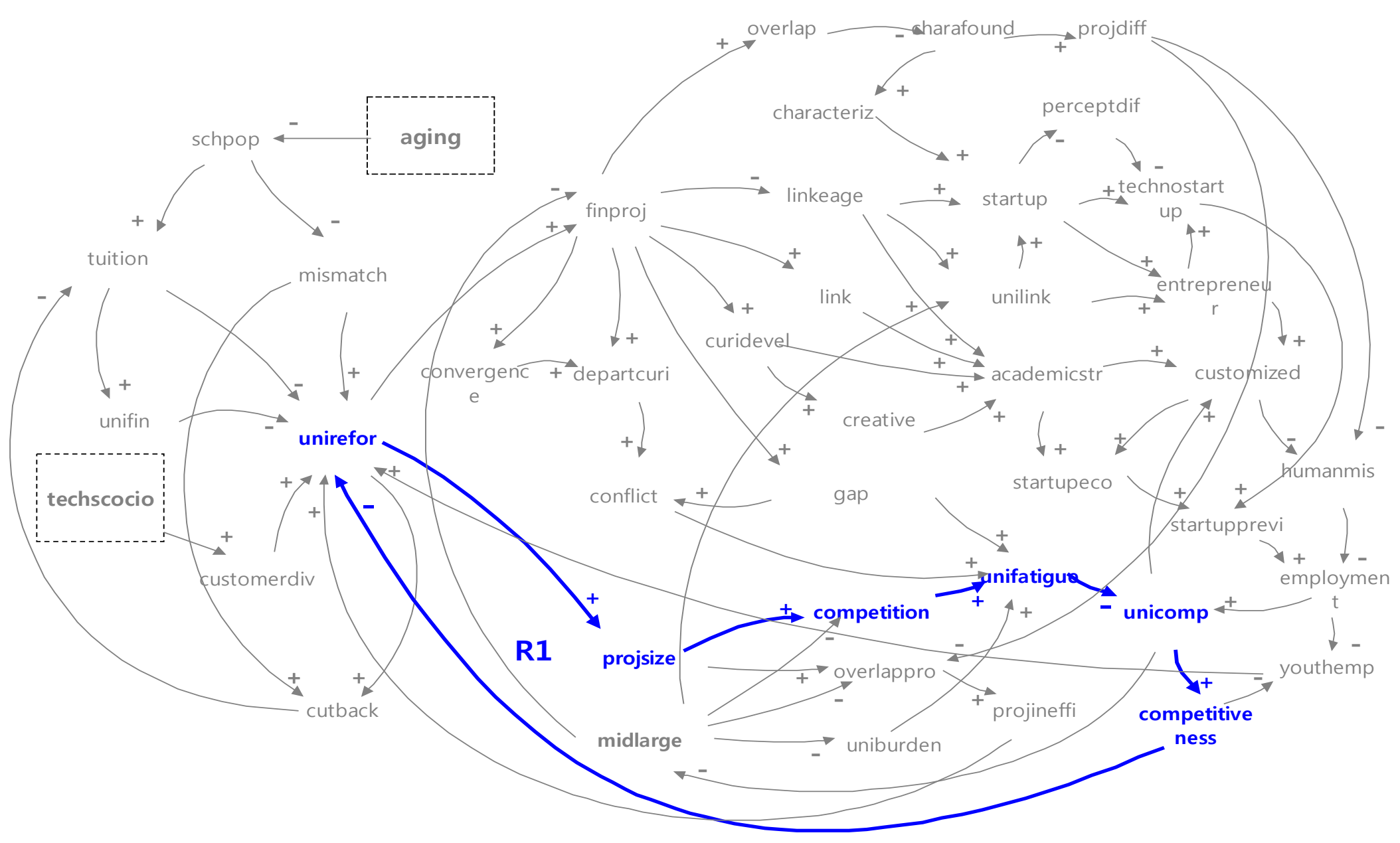

Figure 2. The feedback effect of the scale of the financial support project of the university (Reinforcing Loop: R1) 


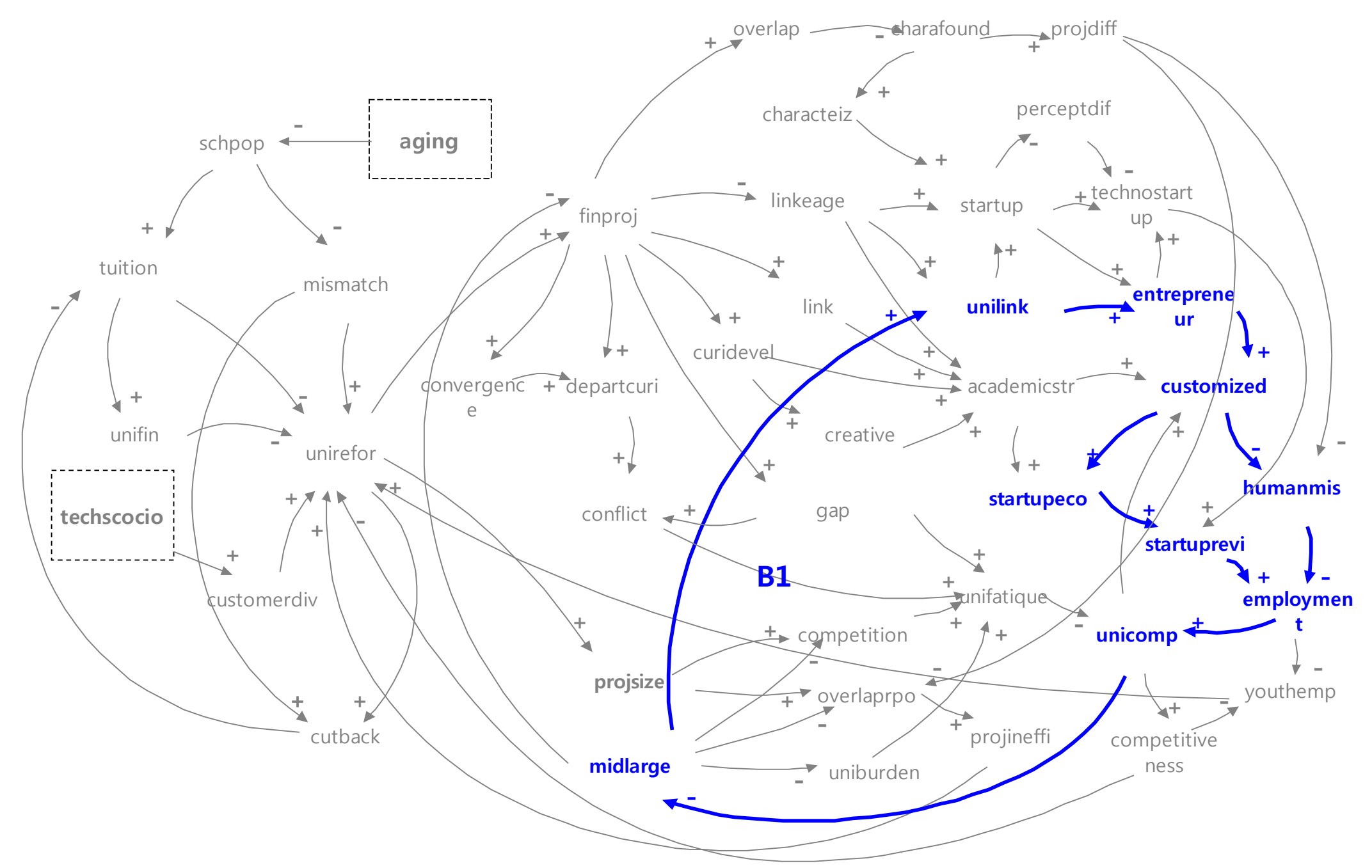

Figure 3. Feedback effect of integration and closure of university financial support project (Balancing Loop: B1) 


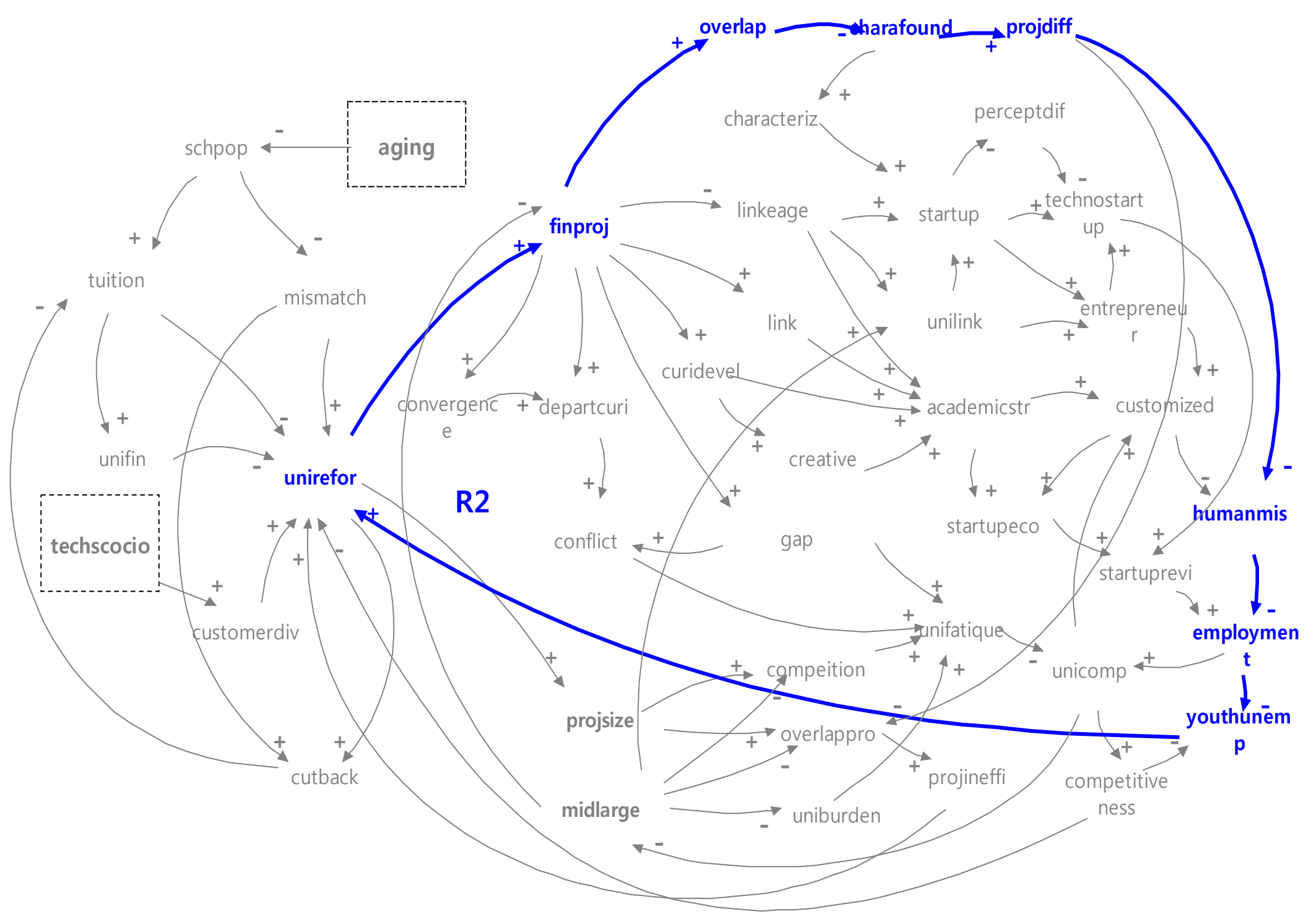

Figure 4. Effectiveness of university reform and job creation feedback (Reinforcing Loop: R2) 


\subsubsection{Social and Industry-oriented Curriculum Restructuring Feedback Effect (Balancing Loop: B2)}

The logic of the loop about the effect of feedback on social and industrial-oriented curriculum restructuring is as follows [Figure 5]. Depending on the necessity of university restructuring, various university financial support projects are made, and the results of development of industry-university cooperation program and development of curriculum are displayed. In addition, it has a virtuous cycle structure in which entrepreneurship is fostered through creative education, establishment of entrepreneurial ecosystem, and cultivation of talents tailored to the region, and customized manpower is cultivated so that employment creation scale, competitiveness of comparative advantages by universities, and competitiveness of university education are achieved.

\subsubsection{Balancing Loop (B3): The Effect of Feedback on the Consolidation of College Financial Support Programs and the Reduction of the University's Fatigue}

The logic of the feedback effect loop of the concluding and closing of the university financial support project and the reduction of the fatigue of the university is as follows [Figure 6]. Due to the consolidation of university financial support projects, there is a prosperity loop in which the competitiveness of the university is enhanced by the reduction of the university's fatigue due to the way of operation as department store, the conflict with the project team and the university headquarters.

\subsubsection{The Effect of Feedback on the University Financial Support Project and Technology Start-up Level (Reinforcing Loop: R3)}

The logic of the feedback effect loop of the university financial support project and the technology entrepreneurial level is as follows[Figure 7]. Support for duplication due to various university financial support projects, foundation of university specialization, reorganization of bachelor's degree, improvement of efficiency of connection between unit businesses will lead to linking entrepreneurship education and technology start-up. As a result, the level of technological entrepreneurship is improved, and entrepreneurship is activated, and the effect of reducing the youth unemployment rate is increased by increasing the size of employment creation.

\subsubsection{Feedback Structure of the Reduction of Enrollment Quota and Tuition Income (Reinforcing Loop: R4)}

The logic of the feedback effect loop of reduction of admission quota and tuition income is as follows [Figure 8]. It is a feedback loop that shows a vicious cycle in which university admission decreases due to the decrease of school age population in aged society, the decrease in tuition income, and the increase in the necessity of university restructuring due to the deterioration of the university budget. 


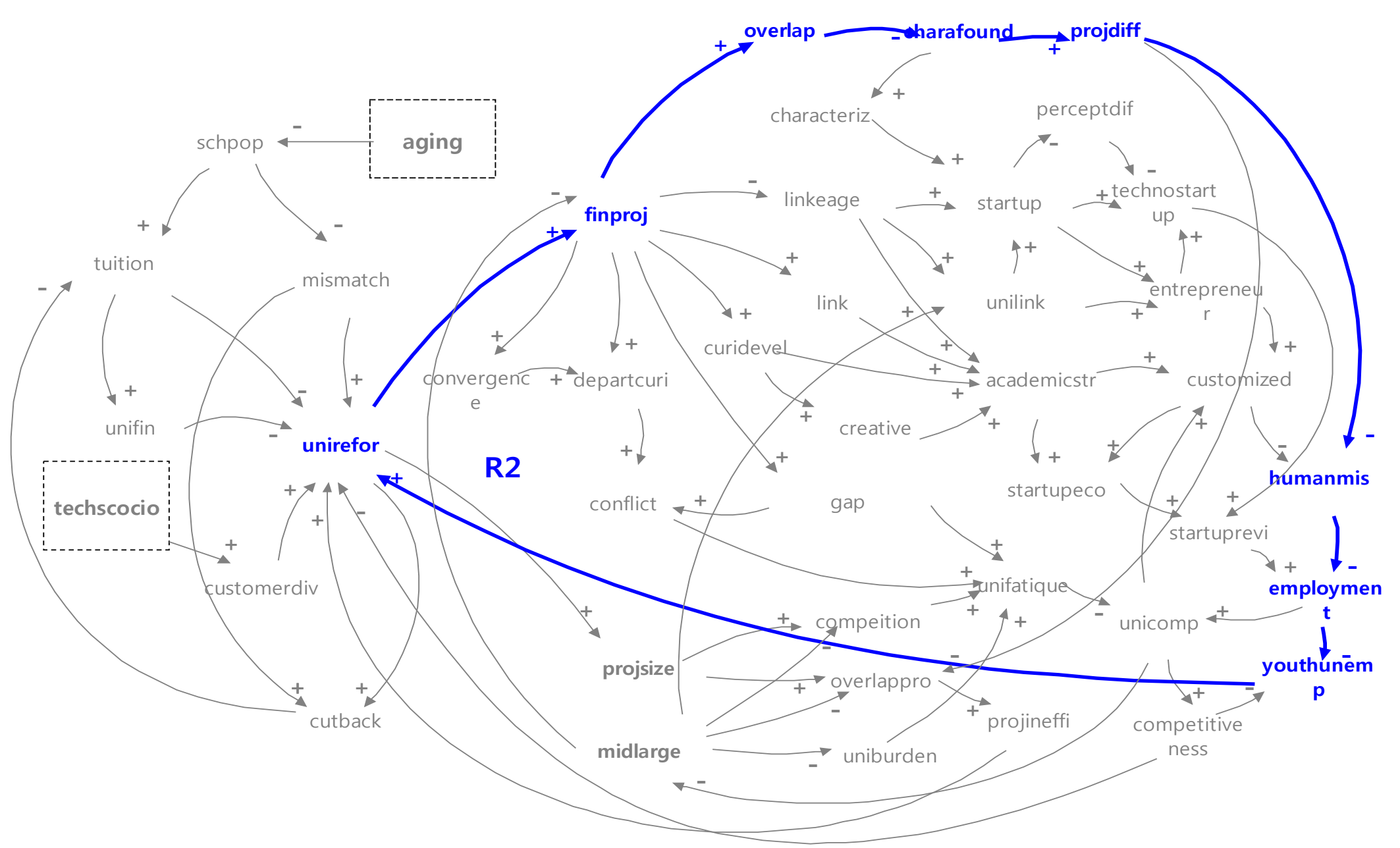

Figure 5. The feedback effect of curriculum reorganization centering on social and industry (Balancing Loop: B2) 


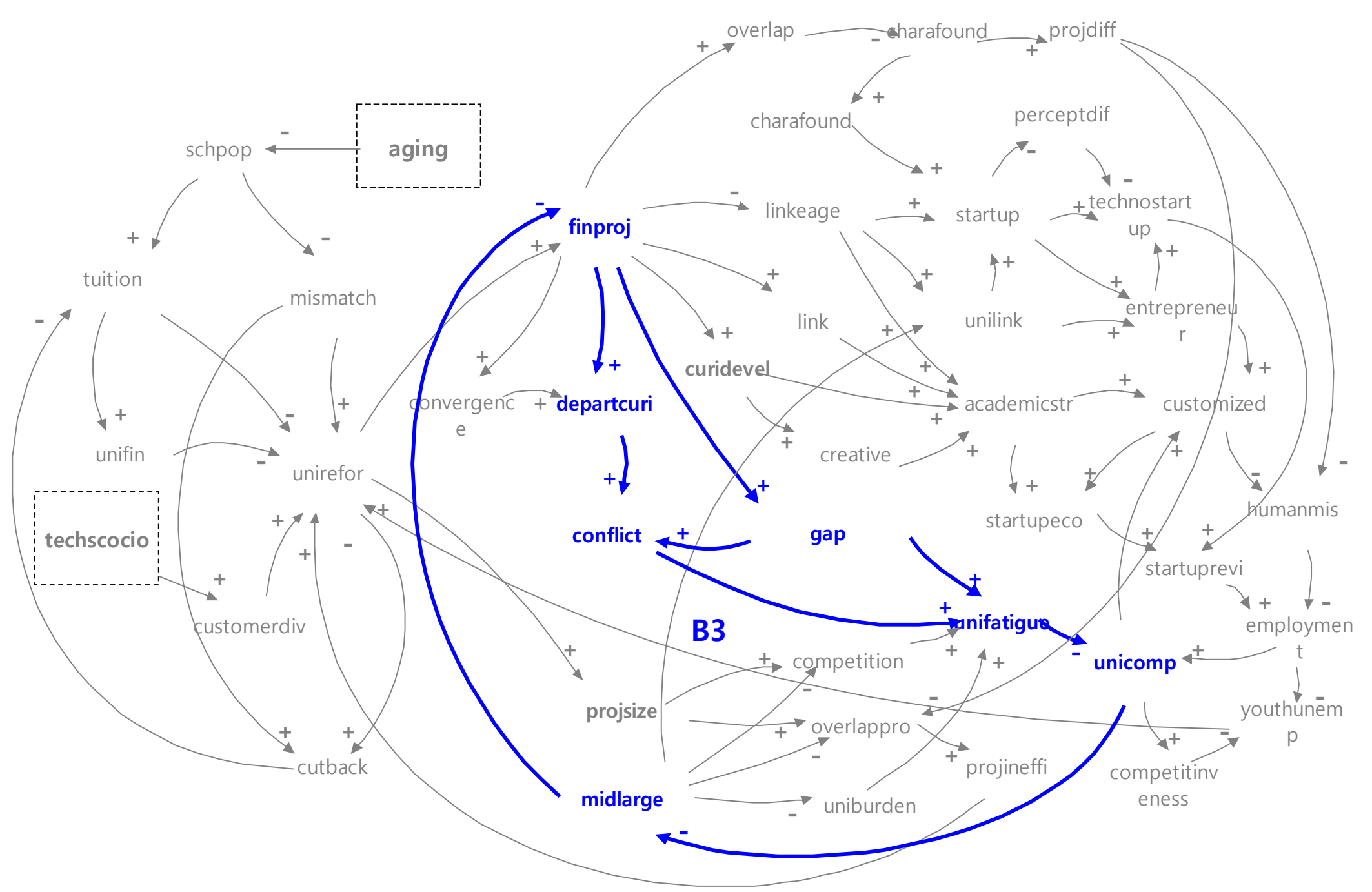

Figure 6. The feedback effect of the consolidation of the university financial support project and the reduction of fatigue of the university(Balancing Loop: B3) 


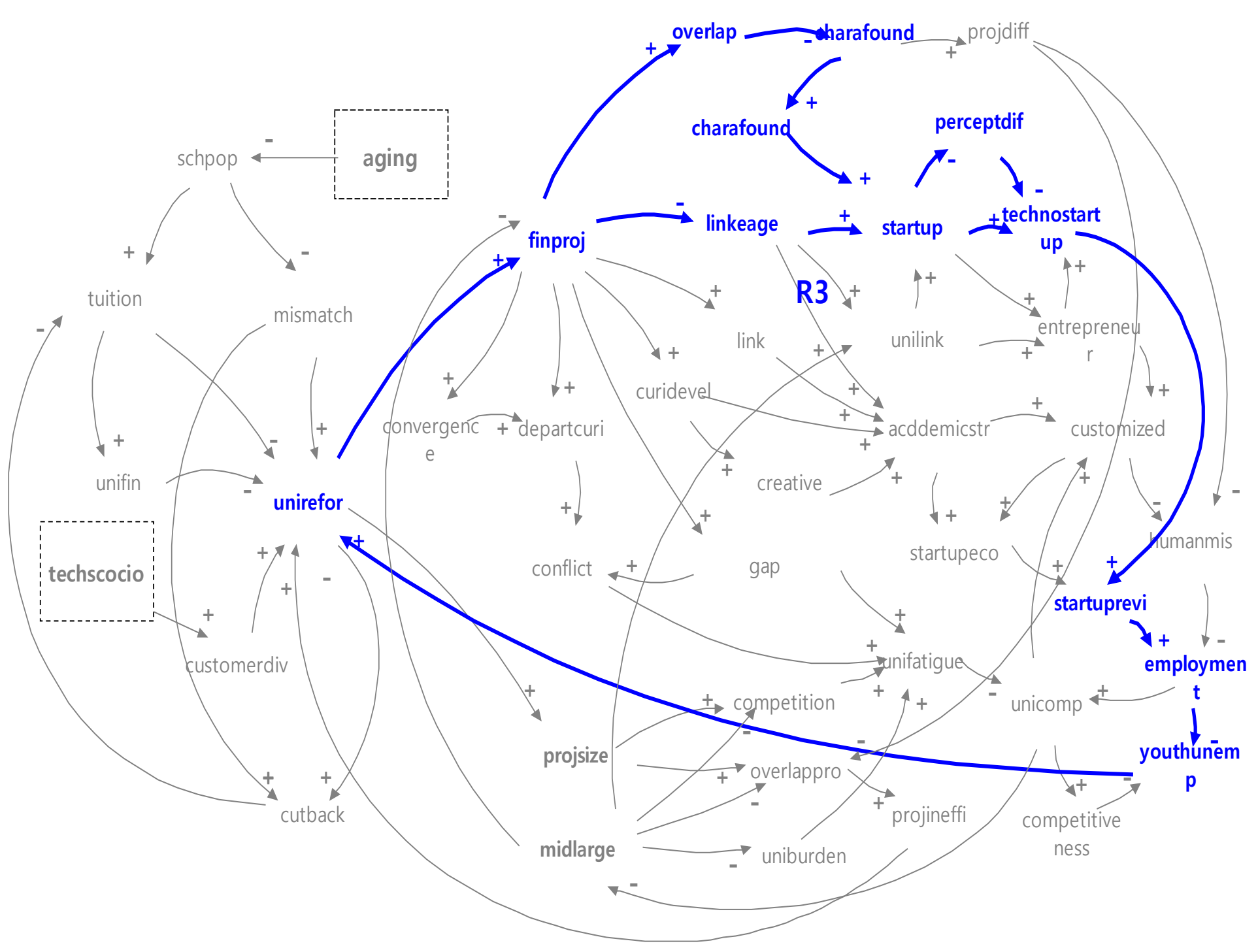

Figure 7. Effectiveness of feedback from university financial support project and technology start-up level (Reinforcing Loop: R3) 


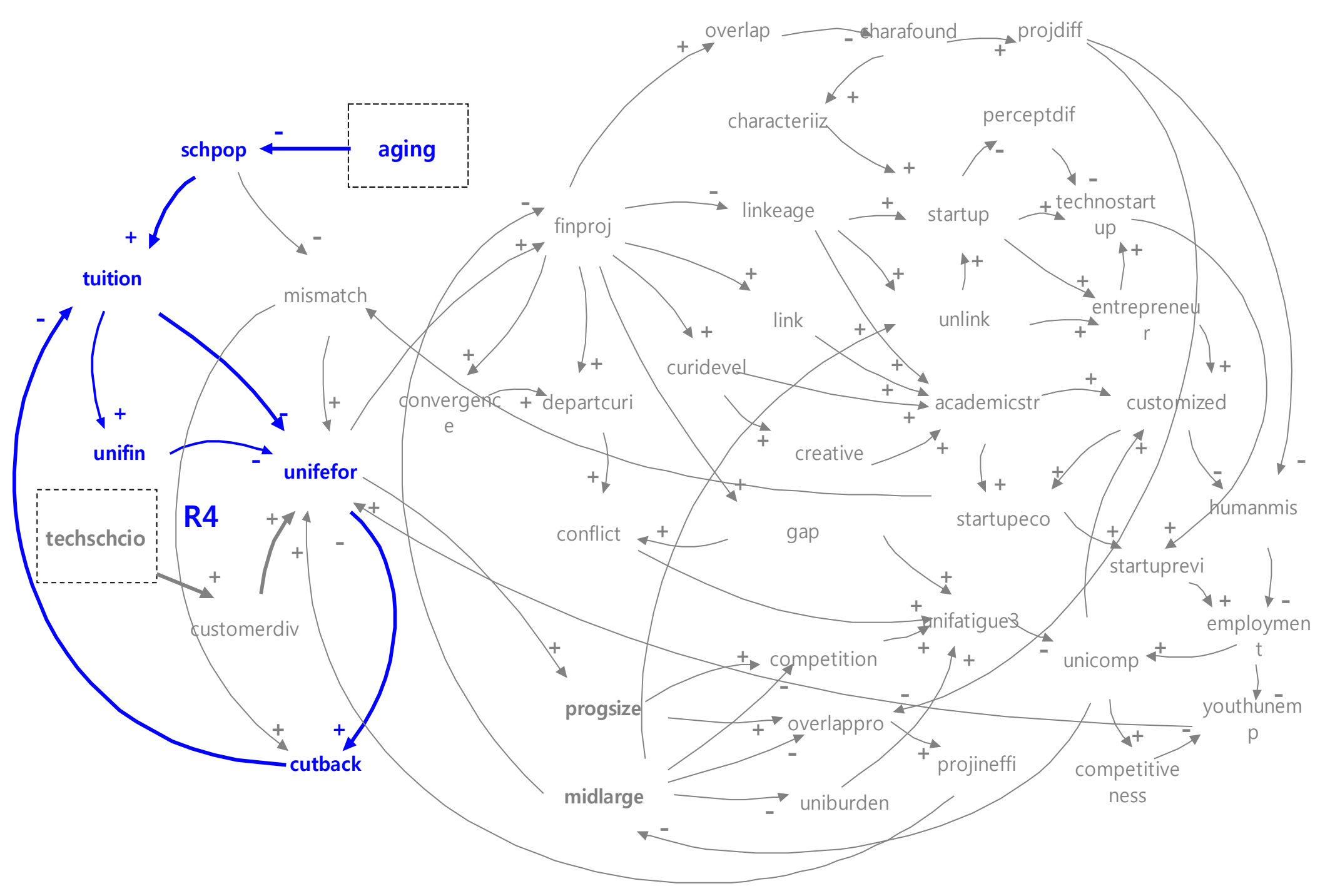

Figure 8. Feedback structure of reduction of admission quota and tuition income (Reinforcing Loop: R4) 


\subsection{Results of Simulation Analysis}

I assumed that the major university financial support projects that have been underway since 2012 will be completed in 2018, and that these projects will be integrated and that the university innovation support project will begin in 2019 as a general financial support project. The simulation results and the sensitivity analysis results of the individual important variables estimated from the improved method, the stronger level by 1.1, and the improved and enhanced level by 1.2 are presented. In the case of university competitiveness variables, which are considered to be the most important, gradual improvement can be expected from 2012 to the promotion of university financial support projects, and it can be assumed that this trend will continue in the long term. If the past level is maintained, it will be 1.65 (assuming 2012 is 1) in 2028. If the University Innovation Support Project is estimated to be a slightly improved scenario from 2019, it will be 1.68 in 2028, and it will be improved to a better level and 1.73 in the stronger level.

When applying these estimates, if the desired level of 2028 is set politically (ex, 1.9 or 2), then to what extent should the level of other variables be improved to achieve this (ex, to what extent the level of the scenario should be improved) may be inferred of estimates.

\section{Policy Implications (Development Direction of University Financial Support Project)}

In evaluating university innovation support projects, we should mainly evaluate how the university intends to strengthen university competitiveness by focusing on the mid- to long-term development plans of universities and the specialization areas of universities. It is necessary to increase the difference in funding between the lower and upper universities. Universities should choose their own methods and strategies for securing professors and professionalism for higher education, and for continually improving the competitiveness of universities $[6,14,18]$. In order for all higher education recipients to have a competent base for their success in the Fourth Industrial Revolution, it is necessary to induce interest and goal setting for learning outcomes as much as invested [7, 11, $12,13,17]$.

University education for the training of human resources to prepare for the 4th Industrial Revolution is not education based on memorization or merely understanding, but education that can raise imagination, creativity, integrated thinking and problem solving skills is needed[8, 14,15,19,20,21]. In order to secure the competitiveness of the university education, it is necessary to legislate the goal of the expansion of the university education finances and the method of securing financial resources [9]. The "Higher Education Financial Grant Act" and the "University Financial Assistance Act" were enacted. The National Financing Plan and the Mid-Term Financial Plan should clearly reflect the funding and investment plans of the university's education [1]. A financial investment plan should be established and implemented for each type of university establishment.

Since the support programs related to the start-up of universities are duplicated, it is necessary to unify the individual business execution organization into the "start-up support team" in order to enhance the effect of the university start-up support project.

Establishment of entrepreneurship education and support system considering various start-up needs such as college students and graduate students, and start-up preparers with social experience after graduation should be built more solidly[10, 16]. In the graduate school, it is necessary to focus on technology entrepreneurship and divide it into two tracks, one for the dissertation preparation track and one for the entrepreneurial track, depending on the consumer. It is necessary to establish a system to cooperate with industries, schools, research institutes and governments in the field of 4 th industrial revolution, to establish a dynamic entrepreneurial ecosystem that enables entrepreneurship and competent entrepreneurs to enter the world [2].

When reforming the financial support program for universities, it is necessary to actively collect opinions about what members of the university (including university headquarters, professor, staff, and students) want. Universities should have ideas to stand up for themselves. The government is not responsible for the universities. Universities should ask themselves. Why should a university exist? To live, universities have to ask themselves how to innovate and find ways to live.

\section{Acknowledgements}

This paper was supported by Konkuk University in 2017

\section{REFERENCES}

[1] Na MJ. Financial support plans for new universities and higher education. University Education. 2017; No. 197.

[2] Ju SH. Re-designing Strategies of Fiscal Programs for Universities to Forster Creative Human Resources in preparation for the Fourth Industrial Revolution. KISTEP Internal Reports. 2017.

[3] Myung SJ, Kim YS, Lee SY. Change Analysis and Development Direction of BK21 PLUS. Korean Journal of Local Government \& Administration Studies. 2017; 31(4): 69-87. 
[4] Ju, SH, Choi YC, Lee SY. Exploring the Future Directions for the Government-Funded University Development Projects Using Social Network Analysis. Korean Governance Review. 2018; 25(1): 237-256.

[5] Lee SY. Advisory Contents. In Ju, Sang-Hyeon. Re-designing Strategies of Fiscal Programs for Universities to Forster Creative Human Resources in preparation for the Fourth Industrial Revolution. KISTEP Internal Reports. 2017; 48-74.

[6] Halder, S. N., \& Chandra, S. Users' Attitudes towards Institutional Repository in Jadavpur University: A Critical Study. International Journal of management and Sustainability, 2012, 1(2), 45-52.

[7] Masciantonio, T. A., \& Berger, P. D. Is Alumni Salary an Appropriate Metric for University Marketers? Journal of Social Economics Research, 2018, 5(1), 1-9.

[8] Ahmed U, Umrani W.A, Pahi M.H, Shah S.M. Engaging PhD students: Investigating the role of supervisor support and psychological capital in a mediated model. Iranian Journal of Management Studies. 2017 Apr 1; 10(2):283-306.

[9] Ha YY, Kim MH. Reorganization plan of university financial support project. Internal report, Ministry of Education. 2017.

[10] Yoon YP. $4^{\text {th }}$ Industrial Revolution and the Future of University Education. University Education. 2017; No. 197.

[11] Pan, C. Y. Effects of Reciprocal Peer-Questioning Instruction on EFL College Students English Reading Comprehension. International Journal of English Language and Literature Studies, 2014, 3(3), 190-209.

[12] Cho YL. Activation Plan for Start up of University Students through Social Big Data Analysis. Korean Comparative Government Review. 2018; 22(1): 155-178.

[13] Dumbu, E. Promoting entrepreneurship through open and distance education in Zimbabwe. A case study of the Zimbabwe Open University students at Masvingo Regional Campus. International Journal of Business, Economics and Management, 2014, 1(6), 101-114.

[14] Esia-Donkoh, K., Amihere, A. K., \& Addison, A. K. Assessment of Student Internship Programme By 2013/2014 Final Year Students of the Department of Basic Education, University of Education, Winneba, Ghana. Humanities and Social Sciences Letters, 2015, 3(2), 105-120.

[15] Owagbemi, G. O. Assessing the Relocation of Adekunle Ajasin University to Akokoland on Transportation System and Rural Development in Ondo State. Humanities and Social Sciences Letter, 2018, 6(2), 51-58.

[16] Wijayanto, H., \& Sumarwan, U. Analysis of the Factors Influencing Bogor Senior High School Student Choice in Choosing Bogor Agricultural University (Indonesia) For Further Study. Journal of Education and e-Learning Research, 2016, 3(3), 87-97.

[17] Akuegwu, B. A., \& Nwi-ue, F. D. Providing Academic Leadership in Universities in Cross River State, Nigeria: Assessment of Departmental Heads' Effectiveness. Asian
Journal of Education and Training, 2017, 3(1), 18-24.

[18] Vahdany, F., \& Gerivani, L. An analysis of the English language needs of medical students and general practitioners: A case study of Guilan University of Medical Sciences. International Journal of English Language and Literature Studies, 2016, 5(2), 104-110.

[19] Verma, C., Stoffova, V., \& Zoltán, I. Perception Difference of Indian Students towards Information and Communication Technology in Context of University Affiliation. Asian Journal of Contemporary Education, 2018, 2(1), 36-42.

[20] Jermsittiparsert K, Sriyakul T, Pamornmast C. The'Populism'Policy and Building-Diminishing Economic'Inequality'and'Unfairness': Empirical Suggestion on Pork-Barrel in Thailand's Rice Trading Business. Public Policy and Administration Research. 2012; 2(7):21-31.

[21] Jayakumar, R. Opinion of the University Teachers towards Educational Television Programmes. American Journal of Education and Learning, 2016, 1(1), 45-52.

[22] Kweka, K. H., \& Ndibalema, P. Constraints Hindering Adoption of ICT in Government Secondary Schools in Tanzania: The Case of Hanang District. International Journal of Educational Technology and Learning, 2018, 4(2), 46-57.

[23] Haseeb M, Abidin IS, Hye Q.M, Hartani N.H. The impact of renewable energy on economic well-being of Malaysia: Fresh evidence from auto regressive distributed lag bound testing approach. International Journal of Energy Economics and Policy. 2018 Dec 7; 9(1):269-75.

[24] Vahdany, F., \& Gerivani, L. An analysis of the English language needs of medical students and general practitioners: A case study of Guilan University of Medical Sciences. International Journal of English Language and Literature Studies, 2016, 5(2), 104-110. 